Original article

\title{
Copper deficiency in Creole goat kids
}

\author{
Diana DrAKSLER ${ }^{\mathrm{a}}$, Martha NúÑEZ ${ }^{\mathrm{a}}$, María Cristina APELla ${ }^{\mathrm{a}, \mathrm{b}}$, \\ Graciela AGÜERO ${ }^{\mathrm{a}, \mathrm{b}}$, Silvia GONZÁLEZ ${ }^{\mathrm{a}, \mathrm{b} *}$ \\ ${ }^{a}$ CONICET-CERELA (Centro de Referencia para Lactobacilos), Chacabuco 145, \\ 4000, Tucumán, Argentina \\ b Universidad Nacional de Tucumán, Ayacucho 491, 4000, Tucumán, Argentina
}

(Received 29 November 2001; accepted 27 May 2002)

\begin{abstract}
Serum copper determination is important to confirm hypocupremia. Twenty healthy kids constituted the Control Group, and sixteen kids with symptoms of copper deficiency, the Problem Group. Animals from the Problem Group showed a low number of red blood cells (RBC) and variations in RBC size and shape. The values found for hemoglobin and mean corpuscular hemoglobin $(\mathrm{MCH})$ in the Control Group were $10.42 \pm 1.34 \mathrm{~g} \cdot \mathrm{dL}^{-1}$ and $33.07 \pm 1.11 \mathrm{~g} \cdot \mathrm{dL}^{-1}$ respectively, while the levels of the Problem Group were $7.95 \pm 1.21 \mathrm{~g} \cdot \mathrm{dL}^{-1}$ and $29.45 \pm 0.78 \mathrm{~g} \cdot \mathrm{dL}^{-1}$, respectively. The kids from the Problem Group presented an important increase in monocytes, neutrophiles and leukocytes; precursor cells of the neutrophile were also observed. The anemia of these animals was hypochromic and macrocytic. Our results indicate that Creole kids with serum copper levels $>450 \mu \mathrm{g} \cdot \mathrm{L}^{-1}$ improved after treatment with copper glycinate. The six goats with cupremia $<450 \mu \mathrm{g} \cdot \mathrm{mL}^{-1}$ were unable to improve their deficiency and died.
\end{abstract}

copper / deficiency / Creole goat / enzootic ataxia / anemia

\section{INTRODUCTION}

Many signs of deficiency, generally non specific, are the result of a lack of several nutrients and often they constitute a depressed nutritional state [4]. On the contrary, the relationships between nutrients and between them and other dietary components, during the development of a deficiency disease, are not clearly defined, as in the relationship between copper, molybdenum and sulfate [15]. Copper deficiency can be primary, when the ingested amounts of copper are inadequate, or it can be

* Correspondence and reprints

E-mail: sgonzal@cerela.org.ar 
secondary or conditioned when the ingested amounts are enough but sulfur or molybdenum is too high. The general symptoms of copper deficiency include a delay in growth, anemia, brittle or fragile bones, hair and/or wool depigmentations and little growth of fleece in sheep, characterized by the loss of the ripple. Lordosis or enzootic ataxia (neurological disease from small ruminants) is associated to copper deficiency of the mother and brood (bringing).

In natural environments a simple deficiency without complications, is not frequently observed, on the contrary to what is achieved in carefully controlled experiments. Hypocupremia in livestock is observed with a higher frequency in the spring and summer, which coincides with the smallest copper content in the grasses at this time. In the autumn, when rains stimulate the growth of the leguminous forages, an increase in the molybdenum content and a diminution in copper content can be observed. Mpofu et al. [18] showed that goats of the Sanyati small holder farming areas (Zimbabwe) have a higher level of copper in the rainy season than in the dry season while calcium, selenium and cobalt are higher in the dry season. The responsive factor of copper secondary deficiency is only known in some cases, and this deficiency is generally attributed to an excess of molybdenum in the diets. This element can induce copper deficiency still when the content of this metal in the grasses is high [5]. An excess of thiomolybdats in the tissues and of molybdenum and sulfate in foods can reduce copper solubility in the digestive tract, inducing a secondary deficiency [15]. A copper-selenium synporter mechanism has been reported because the administration selenium to grazing sheep with copper deficiency, improves the absorption of this latter metal [22]. However, Allen and Miller [2] found that copper does not interfere with the normal metabolism of selenium in lactating goats.

Copper is involved in enzymatic activities related to iron metabolism, collagen and elastin formation, melanin and keratin production and the central nervous system integrity [19].

The general symptoms of copper deficiency include lesions in the spinal cord and the cerebral shaft, and are characterized by myelin deficiency and neuronal degeneration. The initial signs, which are observed from birth until 3 or 4 months of age, include uncoordinated back legs and they are evidenced during the animal's displacement. As the illness progresses, the loss of coordination increases, excessive flexion of the articulations is observed, the animal bends his hands, he balances the back fourth and finally falls. The affection of the latter extremities determines that the animal moves by crawling. Death happens after starvation. There is no true paralysis, the animal can even kick with a lot of energy in the decubitus step. The appetite is not modified [5]. Even though ceruloplasmin or superoxide dismutase activities are more suitable for the determination of copper deficiency, the serum copper method is also used to evaluate this deficiency [14] because it is considered as an easy, swift and thrifty technique.

No bibliographical information about hypo and normal copper in blood is available for Creole goats. For this reason, the objective of this work was to determine cupremia concentration in healthy and copper deficient Creole kids and to obtain information for future studies, where they could be used as reference values.

\section{MATERIALS AND METHODS}

\subsection{Animals}

Thirty-six Creole goat kids aged between 1 and 2 months were considered in this study. All animals were in the weaning period and they were obtained from the Leales farm, Tucumán, Argentina. Twenty animals constituted the Control Group and only healthy kids were included. Sixteen 
animals constituted the Problem Group and only kids with initial symptoms of copper deficiency were included. Both groups were balanced for gender.

\subsection{Samples}

Five $\mathrm{mL}$ of blood were obtained by jugular vein puncture. Each sample was transferred to an assay tube containing heparin to avoid coagulation. The percentages of the red cells were determined immediately. The plasma was obtained by centrifugation (800 $\times g$ during $15 \mathrm{~min}$ ). Copper content in the plasma was determined by atomic absorption spectroscopy using Hitachi $\mathrm{Z}-500$ equipment. The value reported for copper content in the plasma was the mean value obtained from 3 measurements. Copper contents in the drinking places and fresh water from the Leales farm were also determined and the informed value was the mean value obtained from 7 measurements.

\subsection{Treatment}

The goat kids included in the Problem Group were injected three times with $150 \mathrm{mg}$ copper glycinate, first at the beginning of the trial (after blood extraction), the 7 and 14 days later.

\section{RESULTS AND DISCUSSION}

Figure 1 shows an animal with signs of deficiency: the affection of the later extremities determine an excessive flexion of the articulations. Copper contents in plasma from Creole goat kids are shown in Figure 2, and Table I shows blood values from the Creole kids with copper deficiency (Problem Group) and from the Control Group. The animals from the Problem Group showed a low number of red blood cells (RBC). Variations in RBC size and shape (poiquilocyte and fragmentocyte) were observed. Normal values accepted for hemoglobin and mean corpus- cular hemoglobin $(\mathrm{MCH})$ are comprised between $8-12 \mathrm{~g} \cdot \mathrm{dL}^{-1}$ and $30-36 \mathrm{~g} \cdot \mathrm{dL}^{-1}$ respectively, and the Control Group showed $10.42 \pm 1.34 \mathrm{~g} \cdot \mathrm{dL}^{-1}$ and $33.07 \pm 1.11 \mathrm{~g} \cdot \mathrm{dL}^{-1}$ respectively. We found hemoglobin and $\mathrm{MCH}$ values from Creole kids with copper deficiency of $7.95 \pm 1.21 \mathrm{~g} \cdot \mathrm{dL}^{-1}$ and $29.45 \pm$ $0.78 \mathrm{~g} \cdot \mathrm{dL}{ }^{-1}$ respectively; these values were close to the lower range of the normal values. Kids from the Problem Group presented an important increase in neutrophiles and leukocytes; precursor cells of neutrophiles were also observed. These increases could be related to any infectious disease. Monocyte counts were also higher than the normal values obtained for the Control Group.

The copper content in drinking places and fresh water was about $0.47 \pm 0.05 \mu \mathrm{g} \cdot \mathrm{L}^{-1}$; the upper limit of copper in fresh water is $0.5 \mu \mathrm{g} \cdot \mathrm{L}^{-1}$ [12]. Zinc, molybdenum, selenium and arsenic contents in the same water samples were closed to normal values $(0.50$; 0.20 and $0.05 \mu \mathrm{g} \cdot \mathrm{L}^{-1}$ respectively). However, the Leales region is an area characterized by a high content of arsenic (As) in water $\left(0.50 \mu \mathrm{g} \cdot \mathrm{L}^{-1}\right)$. Anke et al. [3] reported that the secretion of As in the milk of control goats does not differ from the levels in the milk of deficient goats. A blood-udder barrier apparently exists that is overcome only by high dietary amounts of As. From our results, studies on the influence of the As content on $\mathrm{Cu}$ absorption are necessary to explain if high As levels in water are involved in the copper deficiency observed in Creole goats.

Plasma copper is recognized to be a more sensitive measure of copper status in animals than whole blood copper [8], but much less than other parameters (ceruloplasmin activity). Copper concentration in plasma obtained from Creole kids included in the Problem Group were lower than the normal values accepted in goats [9] or in sheep [5, 23]. Generally data from sheep [10] are used as the standard because the copper content from the healthy caprine herd was not fully standardized. Church [6] determined that 


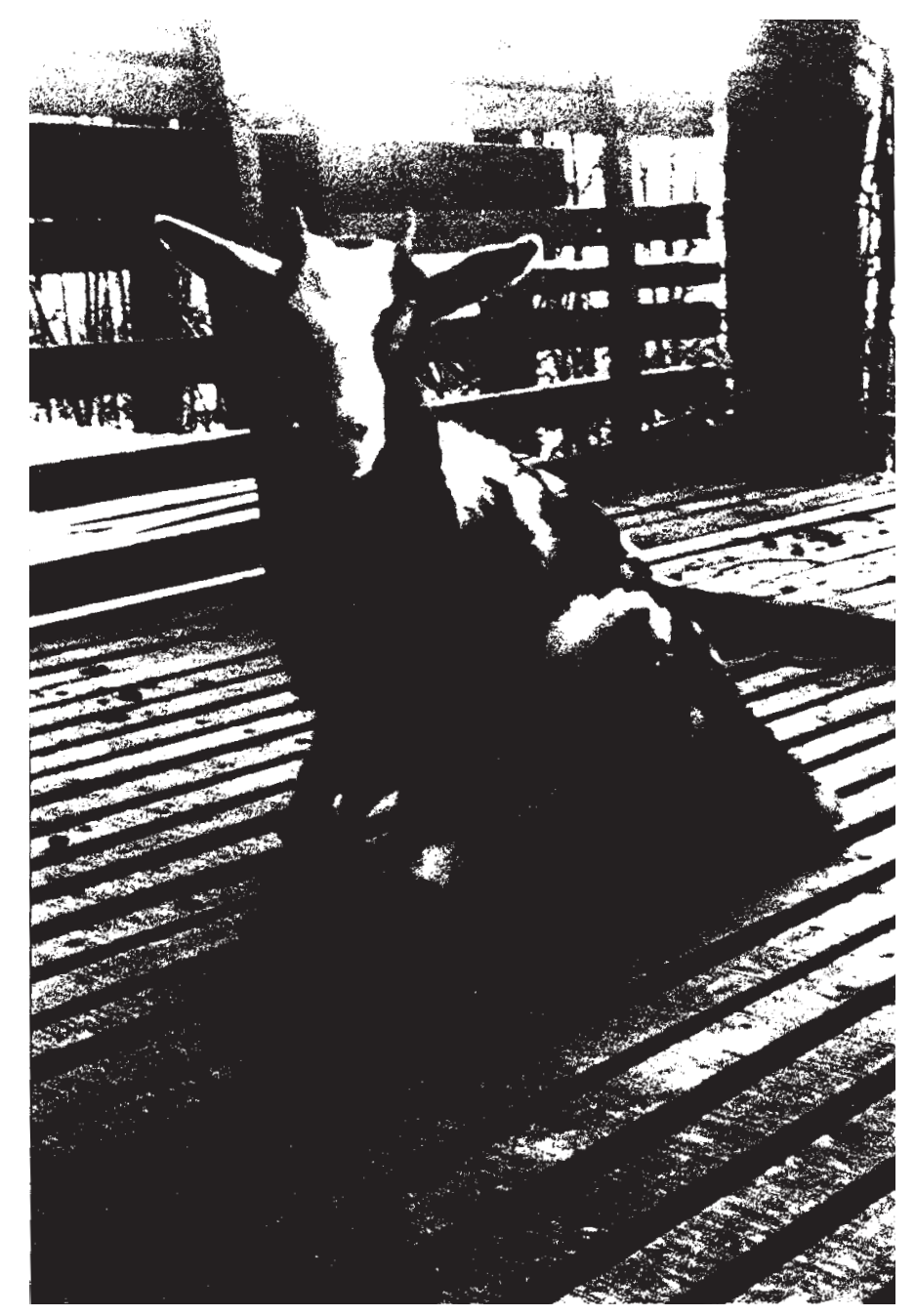

Figure 1. Creole goat kids in the decubitus step.

copper concentrations in plasma from sheep are related to age: $0.26 \mu \mathrm{g} \cdot \mathrm{mL}^{-1}$ in the fetus; $0.63 \mu \mathrm{g} \cdot \mathrm{mL}^{-1}$ in the newborn and $1.02 \mu \mathrm{g} \cdot \mathrm{mL}^{-1}$ in adults. Ahmed et al. [1] showed that an association exists between age and the physiological status of dairy Nubian goats, pregnancy or lactation and blood concentration of zinc ( $\mathrm{Zn}$ ) and copper $(\mathrm{Cu}) . \mathrm{Cu}$ plasma levels increased significantly in adults compared to second and third kiddings as well as in pregnant animals. Sometimes the cupremia value is unable to infer the copper content in the liver but levels of this metal in plasma $\leq 0.5 \mu \mathrm{g} \cdot \mathrm{mL}^{-1}$ indicate low concentration in liver. This organ has the highest levels of copper in several animals including small ruminants [16]. Generally copper levels in the blood $<0.7 \mu \mathrm{g} \cdot \mathrm{mL}^{-1}$ diagnose a copper deficiency. Faye and Grillet [9] reported copper levels in goat's blood at about $0.4 \mu \mathrm{g} \cdot \mathrm{mL}^{-1}$ but these animals did not present clinical symptoms of enzootic ataxia. Roeder [20] found this pathology in kids from the Ethiopian Rift Valley, but this study was not specific 
for goats. In the present work, we obtained blood copper levels in Creole goats at about $0.5 \mu \mathrm{g} \cdot \mathrm{mL}^{-1}$, together with a clinical expression of enzootic ataxia. Apparently Creole goats are more sensitive to copper deficiency than the goats that were considered in the study carried out by Faye and Grillet [9]. On the contrary, the primary copper deficiency levels were lower than the conditioned or secondary deficiency $\left(0.1-0.3 \mu \mathrm{g} \cdot \mathrm{mL}^{-1}\right.$ and $0.4-0.7 \mu \mathrm{g} \cdot \mathrm{mL}^{-1}$, respectively) [8]. The primary copper
Figure 2. Levels of serum copper in Creole goat kids.

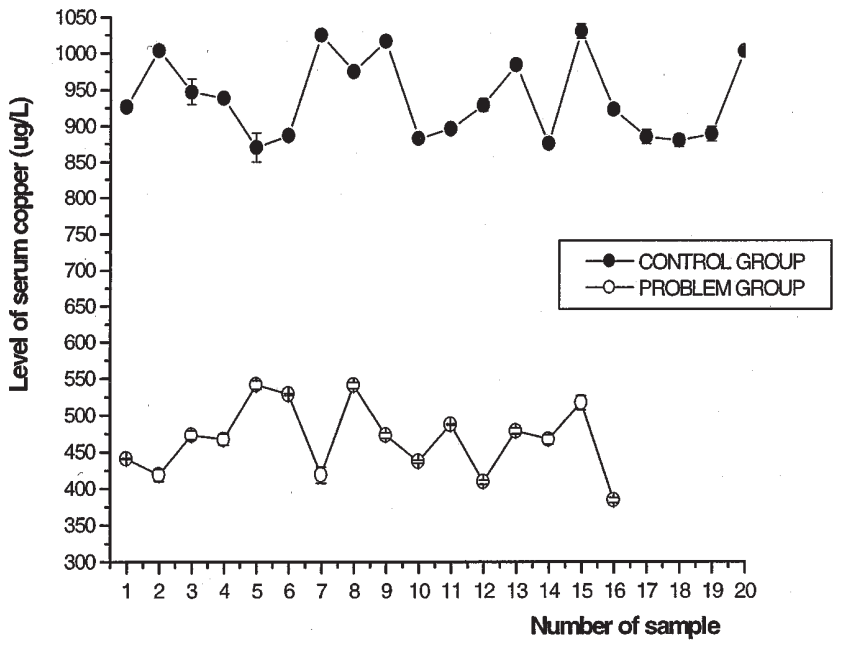

* Samples 1, 2, 7, 10, 12 and 16: ineffective treatment with copper glycinate.

Table I. Mean hematic values from Creole kids with copper deficiency.

\begin{tabular}{lcccc}
\hline Assays & Units & $\begin{array}{c}\text { Problem group } \\
\text { (copper deficient kids) }\end{array}$ & $\begin{array}{c}\text { Control group } \\
\text { (healthy kids) }\end{array}$ & $\begin{array}{c}\text { Reference } \\
\text { values }^{\mathrm{a}}\end{array}$ \\
\hline Hematocrit & $(\%)$ & $27.00 \pm 1.41$ & $31.28 \pm 1.17$ & $22-38$ \\
Hemoglobin & $\left(\mathrm{g} \cdot \mathrm{dL}^{-1}\right)$ & $7.95 \pm 1.21$ & $10.42 \pm 1.34$ & $8-12$ \\
Hemoglobin CM & $\left(\mathrm{g} \cdot \mathrm{dL}^{-1}\right)$ & $29.45 \pm 0.78$ & $33.07 \pm 1.11$ & $30-36$ \\
Erythrocyte & $\left(\times 10^{6} \cdot \mathrm{dL}^{-1}\right)$ & $2.97 \pm 0.16^{*}$ & $13.92 \pm 2.03^{*}$ & $8-18$ \\
Leukocyte & $\left(\times 10^{3} \cdot \mathrm{dL}^{-1}\right)$ & $18.00 \pm 3.49$ & $10.70 \pm 1.75$ & $4-13$ \\
Neutrophile & $\left(\times 10^{3} \cdot \mu \mathrm{L}^{-1}\right)$ & $12.83 \pm 1.18$ & $3.69 \pm 0.91$ & $1.2-7.2$ \\
Immature neutrophile & $\left(\times 10^{3} \cdot \mu \mathrm{L}^{-1}\right)$ & $71.28 \pm 6.56^{* *}$ & $34.49 \pm 3.27 * *$ & $30-48$ \\
& $(\%)$ & $1.78 \pm 0.11$ & $0.11 \pm 0.02$ & seldom \\
Lymphocyte & $\left(\times 10^{3} \cdot \mu \mathrm{L}^{-1}\right)$ & $3.53 \pm 0.31$ & $6.03 \pm 0.01$ & \\
Monocyte & $(\%)$ & $19.61 \pm 1.72^{* *}$ & $60.84 \pm 8.55^{* *}$ & $50-70$ \\
& $\left(\times 10^{3} \cdot \mu \mathrm{L}^{-1}\right)$ & $1.32 \pm 0.21$ & $0.39 \pm 0.11$ & $0-0.55$ \\
& $(\%)$ & $7.33 \pm 1.16^{*}$ & $3.64 \pm 0.51 *$ & $0-4$ \\
\hline
\end{tabular}

${ }^{a}$ Merck [15]. $* P<0.05 . * * P<0.01$. 
deficiency is due to an insufficient supply on ranges, while the secondary copper deficiency is due to a marked excess of molybdenum in grasslands. Galbraith et al. [11] determined that elevated molybdenum intake was not severe or long enough to produce clinical symptoms or to affect growth, hematological status or mohair fiber production of growing Angora goats. The animals included in the Problem Group presented weakness and paleness in their mucous membranes, which were related to low values of red cells. The anemia observed in Creole goats from the Problem Group could be a ferropenic-type anemia, which is hypochromic and macrocytic $[7,15]$. The bioavailable copper must be in adequate levels for the formation of red cells. On the contrary, ceruloplasmin concentration is directly related to copper absorption and usefulness; therefore a decrease of ceruloplasmin induces anemia [13].

The kids seriously affected with copper deficiency, have difficulty in surviving since no treatment gives satisfactory results. When the deficiency is incipient, the kids can receive products containing bioavailable copper as a treatment. Our results indicate that Creole kids with serum copper levels $>450 \mu \mathrm{g} \cdot \mathrm{L}^{-1}$ reverted their deficiency after treatment with copper glycinate (Fig. 2) The six goats from the Problem group with cupremia $<450 \mu \mathrm{g} \cdot \mathrm{L}^{-1}$ were unable to improve their deficiency and finally these animals died.

Prevention is usually very effective and should be practiced fundamentally in those farms where the problems of copper deficiency has been previously presented. Since the fetus's copper requirement constantly increases during the course of gestation, pregnant goats and sheep should receive a copper supplement during the last three months of pregnancy. The copper requirement of a sheep fetus almost increases 6 times between the first third and the second third of gestation and this last level is duplicated in the final third [17]. Williams et al.
[24] reported that in the non-liver compartment of fetal lambs at the end of pregnancy a little more than $2 \mathrm{mg} \mathrm{Cu}$ is deposited $/ \mathrm{kg}$ live-weight gain. If it is assumed that little postnatal change occurs, then with a gain in live-weight of 150-200 g/day the hepatic store of $\mathrm{Cu}$ would be exhausted in approximately 2 weeks in the event of a lactation deficit. In the present study, the farmer ignored the importance that represented to know, for future treatments, the copper content in the livers of the dead Creole kids. He did not inform the laboratory and for this reason, in the present work, hepatic copper levels could not be determined.

The preparations of mineral licks (salt blocks) dedicated to sheep and bovine should contain copper sulfate $0.25-0.50 \%$ and $2 \%$ respectively. Sheep are very sensitive to copper toxicity, which therefore explains the small concentration of their salt blocks [5]. Goats are very sensitive to copper deficiency and resistant to the toxicity of this metal; for this reason goats should receive mineralized salt for bovines $[15$, 21].

Our results represent the first information on copper deficiency in Creole goats in Argentina. However, a prevention program on copper deficiency may be practiced in the Leales farms. The first step was to determine copper, zinc, molybdenum, selenium and arsenic contents in drinking places and fresh water; the results obtained were closed to the standard values established by the International Codes, except As. Studies on the content of these elements in the grasses growing in the Leales area are underway.

\section{ACKNOWLEDGMENTS}

The authors are thankful for the support from the Grants from CIUNT (26-D-126) and from Academia Nacional de Agronomía y Veterinaria (Alimentos probióticos para ganado caprino). CONICET is also gratefully recognized. 


\section{REFERENCES}

[1] Ahmed M.M., Hamed T.F., Barri M.E., Variation of zinc and copper concentrations in the plasma of Nubian goats according to physiological state, Small Rumin. Res. 39 (2001) 189-193.

[2] Allen J.C., Miller W.J., Transfer of selenium from blood to milk in goats and noninterference of copper with selenium metabolism, J. Dairy Sci. 64 (1981) 814-821.

[3] Anke M., Krause U., Groppel B., The effect of arsenic deficiency on growth, reproduction, life expectancy and disease symptoms in animals, Proc. Symposium Trace Subst. in Environm. Health XXI, University Missouri, Columbia, MO, USA, 1987.

[4] Arnhold W., Anke M., Glei M., Rideout B., Stalis I., Lowenstine L., Edwards M., Schüppel K.F., Eulenberger K., Nötzold G., Determination of copper status in ruminants, Trace Elem. Electrol. 15 (1998) 65-69.

[5] Blood D.C., Henderson J.A., Radostits O.M. Medicina Veterinaria, $5^{\mathrm{a}}$ edición, Editorial Interamericana, México, D.F., 1987, pp. 924-933.

[6] Church C.D., El rumiante: fisiología digestiva y nutrición, Editorial Acribia S.A., Zaragoza, España, 1993, pp. 397-408.

[7] Church C.D., Pond W.G., Fundamentos de nutrición y alimentación de animales, Editorial Limusa S.A. de C.V. Grupo Noriega Editores, México, D.F., 1998, pp. 189-192.

[8] Claypool D.W., Adams F.W., Pendell H.W., Hartmann N.A. Jr., Bone J.F., Relationship between the level of copper in the blood plasma and liver of cattle, J. Anim. Sci. 41 (1975) 911-914.

[9] Faye B., Grillet C., La carence en cuivre chez les ruminants domestiques de la région d'Awash (Ethiopie), Rev. Elev. Méd. Vét. Pays Trop. 37 (1984) 42-60.

[10] Fraser A., Stamp J.T., Ganado ovino: Producción y enfermedades, Ediciones Mundi-Prensa, Madrid, España, 1989, pp. 275-276.

[11] Galbraith H., Chigwada W., Scaife J.R., Humphries W.R., The effect of dietary molybdenum supplementation on tissue copper concentrations, mohair fibre and carcass characteristics of growing Angora goats, Animal Feed Sci. Technol. 67 (1997) 83-90.

[12] Kogiso M., Schindler V., Calidad del Agua para bebida animal, Rev. CREA 78 (1979) 26-36.

[13] Lee G.R., Cartwright G.E., Wintrobe M.M., Heme biosynthesis in copper deficient swine, Proc. Soc. Exp. Biol. Med. 127 (1968) 977-981.

[14] Luginbuhl J.M., Poore M.H., Spears J.W., Brown T.T., Effect of dietary copper level on performance and copper status of growing meat goats, Sheep Goat Res. J. 16 (2000) 65-71.

[15] Merck, El Manual de Veterinaria Merck \& Co. Inc., $4^{\mathrm{a}}$ edición, Océano / Centrum, Barcelona, España, 1993, pp. 1285-1288, 1892-1894.

[16] Miller J.K., Ramsey N., Madsen F.C., Elementos vestigiales, in: Church C.D., Editorial Acribia S.A., El rumiante: fisiología digestiva y nutrición, Zaragoza, España, 1988, pp. 397-408.

[17] Moss B.R., Madsen F., Hansard S.L., Gamble C.T., Maternal-Fetal Utilization of copper by sheep, J. Anim. Sci. 38 (1974) 475-479.

[18] Mpofu I.D.T., Simoyi M.F., Ndlovu L.R., An assessment of the status of goats under smallholder management, Transactions of the Zimbabwe Scientific Association 72 (1998) 11-13.

[19] National Research Council, Mineral Tolerances of Domestic Animals, Natl. Acad. Sci., Washington D.C., 1980.

[20] Roeder P.L., Enzootic ataxia of lambs and kids in the Ethiopian Rift Valley, Trop. Anim. Health Prod. 12 (1980) 229-233.

[21] Soli N.E., Nafstad I., Effects of daily oral administration of copper to goats, Acta Vet. Scand. 19 (1978) 561-568.

[22] Thomson G.G., Lawson B.M., Copper and selenium interaction in sheep, N.Z. Vet. J. 18 (1970) 79-82.

[23] Tschopp J.C., Althaus R.L., Gervasio S. Malinskas G., Aplicación de la bioquímica sanguínea como método complementario para el análisis del estado nutricional de un rodeo de ovinos con signos de hipocupremia, Therios 144 (1998) 332-334.

[24] Williams R.B., McDonald I., Bremner I., The accretion of copper and of zinc by the fetuses of prolific ewes, Br. J. Nutr. 40 (1978) 377-386.

To access this journal online: www.edpsciences.org 